\title{
Ameliyathanede Çalışan Sağlık Personelinin İş Sağlığı ve Güvenliği Algısının Belirlenmesi
}

\author{
Determination of Occupational Health and Safety Perceptions \\ in Health Professional Works at Operating Room
}

Yasin ŞENTÜRK, Nihal SUNAL

\begin{abstract}
ÖZET
$\mathrm{Bu}$ çalışma ameliyathanede çalışan sağlık personelinin iş sağlığı ve güvenliği algısının belirlenmesine yönelik tanımlayıcı olarak yapılmıştır. Araştırmanın örneklemini Medipol Sağlık Grubu Hastanelerinin ameliyathanelerinde Nisan 2017 ve Eylül 2017 tarihleri arasında sağlık personeli olarak çalışanlar oluşturmuştur. Çalışmanın verilerini çalışanlara ait "Sosyo-Demografik Veri Formu" ve "Hastanede Çalışan Sağlık Personeli İçin İş Güvenliği Ölçeği” kullanılarak toplanmıştır. Memnuniyet düzeyi yüksek olan personelin iş sağlığı ve güvenliği eğitimi almamış olsa dahi ölçekten yüksek puan aldığı belirlenmiştir. Daha büyük araştırmalarla İş Sağlığı ve Güvenliği algısı ölçülmeli ve sonuçlar grupla paylaşılarak farkındalık geliştirilmelidir.
\end{abstract}

Anahtar Kelimeler: Ameliyathane, İş Kazası, İş Sağlığı ve Güvenliği, Meslek Hastalığı, Sağlık Personeli

\section{ABSTRACT}

This study was conducted to determine occupational health and safety perceptions in health professional who works at operating room, as descriptive. The sample of the study was constituted of health professionals work at operating rooms in Medipol Health Group Hospitals between April-September 2017. Data was collected by using 'Sociodemographic Data Form' of professionals and 'Occupational Safety Scale for Health Professionals in Hospitals'. It was determined that health professional who had got high satisfaction level had also high level fort his scale, even though they didn't take Occupational Health and Safety Education. Occupational Health and Safety perception should be evaluated in more large studies and results should be shared for awareness.

Keywords: Operating room, Occupational Accident, Occupational Health and Safety, Occupational Disease, Health Professionals

\section{Yasin ŞENTÜRK}

yasinsenturk@hotmail.com

Dr.Öğr.Üyesi Nihal SUNAL — İstanbul Medipol Üniversitesi, Sağlık Bilimleri Fakültesi, İstanbul, Türkiye

Assist. Prof. Dr. Nihal SUNAL — Istanbul Medipol University, Faculty of Health Sciences, Istanbul, Turkey

nsunal@medipol.edu.tr 


\section{GİRIŞ}

İnsan hayatının büyük çoğunluğu işyerinde geçmektedir. Çalışma hayatında fiziksel, kimyasal, biyolojik ve psiko -sosyal birçok faktör bulunmakta ve dolayısıyla da kişinin sağlık, güvenlik ve verimliliği bu faktörlerin etkisi altında kalmaktadır [1]. Bu nedenle; çalışma hayatının insan sağlığı üzerinde önemli etkileri vardır. Bu etkiler hem çalışanların sağlığı hem de çevre ve toplum sağlığı bakımından da değer teşkil etmektedir. Dünya Sağlık Örgütü sağlığı, "sadece hastalık ve sakatlığın olmayışı değil, kişinin fiziksel, ruhsal ve sosyal olarak da tam bir iyilik halinde olması" olarak tanımladığından bu etkilerin incelenmesi ve olumsuz etkilerinin önlenmesi 'işs sağlığı ve güvenliği' biliminin amacını oluşturarak, geniş bir çerçeveden bakmayı gerektirir [2].

Çalışma ve yaşam güvenliğinin sağlanamadığı, iş bulma olasıllı̆ıının gittikçe azaldığı, gelir dağılımının dengesizliğinden dolayı huzursuzlukların giderilemediği toplumlarda kişinin tam iyilik halinde olması beklenemez [3]. On altınc1 ve on yedinci yüzyıllarda yaşanan bir takım sosyoekonomik olaylar ve gelişmeler çalışma hayatında iş sağlığ ve güvenliğiyle ilgili konular açısından önemli etkiler yaratmıştır. Dünyada ve ülkemizde meydana gelen teknolojik gelişmeler ve özellikle sanayi devrimiyle birlikte çalşsanlar için ortaya çıkan olumsuz koşullar sebebiyle, çalışanlar iş sağlığı ve güvenliğiyle ilgili sıkıntılar yaşamaya başlamıştır [4].

İş sağlığı ve güvenliği çalışmaları çalışan insanları; hastalık, kaza gibi risk ve tehlikelerden korumayı amaçlayan çalışmalardır. Bu çalışmaların ana amaçları; çalışanların psikolojik ve fizyolojik sağılıklarını koruyarak sürdürmek, sağlıklı, rahat ve güvenli çalışma ortamı sunarak iş kazaları ve meslek hastalıklarına karşı korumaktır [5].

Sanayileşme ve teknolojik gelişmelerin artmasıyla bir- likte, özellikle işyerlerinde çalışanların güvenlikleri ile ilgili olarak sorunlar ortaya çıkmaya başlamıştı. Sorunların oluşmaması için gerekli olan tüm önlemleri alarak çalışma ortamlarını güvenli hale getirmek gerekmektedir. İşs sağlığı ve güvenliği de bu özelliğinden dolayı önemlidir [6].

ILO ve WHO iş sağlı̆ı̆ını, "Çalışan tüm insanların fiziksel, ruhsal, moral ve sosyal yönden tam iyilik hallerinin sağlanması ve en üst düzeyde sürdürme çalışmalarıdır. İşin koşuları ve zararlı maddeler nedeniyle çalışanların sağlı̆ına gelebilecek zararların önlenmesi ve çalışanın özelliklerine uygun yerlere yerleştirilmesini, işin insana, insanın da işine uyumunun sağlanması gerektiğini ele alan tıp bilimi” olarak ifade etmişlerdir [7].

Ameliyathaneler, hasta ya da yaralının hastalık ya da travma sonucu vücut bütünlüğünün bozulması durumunda, yüksek teknolojik araç ve gereçlerin kullanılarak, yeni bilgiler ışı̆̆ında çeşitli ameliyat tekniklerinin uygulandığı, ekip çalısmasının beraberinde, hayati kararların alındığı cerrahi bir ortamdır [8].

Ameliyathanede sağ lık çalışanlarını iş sağ lı̆̆ı ve güvenliği yönünden tehdit eden çeşitli risk ve tehlikeler bulunmaktadır. "Amerikan Ulusal Mesleki Sağlık ve Güvenlik Enstitüsü, hastanelerde 29 çeşit fiziksel, 25 çeşit kimyasal, 24 çeşit biyolojik, 6 çeşit ergonomik ve 10 çeşit psikososyal tehlike ve risk olduğunu bildirmiştir” [9].

Türk Dil Kurumu sözlüğüne göre "Ameliyat; Hasta üzerinde tedavi amacıyla uygulanan kesme ve dikme işlemi, cerrahi müdahale ve operasyona, Ameliyathane ise; Hastanelerde hastaların ameliyat edildiği özel bölüm” olarak tanımlanmaktadır [10].

Ameliyathane odaları, sağlık personelinin steril olarak giyinebilmelerine, hastanın steril olarak örtülmesine ve sağlık personelinin hareket edebilmesine olanak sağlayacak ve anestezi ekibinin çalşşmasına engel olmayacak şekilde ve 
boyutta olmalıdır. En ufak boyuttaki bir ameliyathanenin $6 \times 6=36 \mathrm{~m} 2$, açı kalp cerrahisi ve beyin cerrahisi operasyonları için $54 \mathrm{~m} 2$, endoskopi, sistoskopi ve bazı tanısal ayaktan cerrahi operasyonlar için odaların $18 \mathrm{~m} 2$ lik bir alanda olması yeterlidir [11].

Ameliyathane ünitelerinin yüksek hijyen standardının sağlanabilmesi için yapımı sırasında zemin, duvar, tavan, kapılar, pencereler ve aydınlatma için kullanılan malzemelerin kolay dezenfekte edilebilmesi, dezenfeksiyon maddelerine dayanıklı olması, toz tutmaması ve üzerinde mikropların üremesine sebep olabilecek pürüzlerle aralıklarının olmamasına dikkat edilir. Ameliyathanenin içerisine yerleştirilen gaz boruları, havalandırma parmaklıkları, lambalar, malzeme dolapları gibi donanımlar mutlaka tavan ve duvarların içerisine görünmeyecek şekilde yerleştirilmiş olmalıdır. Özelikle duvar, tavan, aydınlatma sistemlerinin ve kapıların yapılmasında özel bir itina gereklidir [12].

Ameliyathanelerde fiziksel risk etmenleri olarak havalandırma, aydınlatma, gürültü ve radyasyon, kimyasal risk etmenlerinden ise cerrahi duman, lazer, lateks alerjisi, sabun ve deterjanlar, sterilizasyon amaçlı kullanılan maddeler ve atık gazlar en sık karşılaşılan tehlikelerdendir. Enfeksiyon hastalıkları, kesici-delici alet yaralanmaları en sık karşılaşılan biyolojik riskler iken, kas-iskelet bozuklukları ise en sık görülen ergonomik risklerdir. Uzun mesai saatleri, iş yükü ve iş hızı da psiko-sosyal risk grupları olarak sık görülmektedir. Sağlık çalışanları ameliyathane ortamındaki risklerden dolayı iş kazası geçirmekte ve meslek hastalıklarına yakalanmaktadır.

\section{YÖNTEM}

\section{A. Araştırmanın Amacı ve Şekli}

Bu araştırma ameliyathanelerde çalışan sağlık personelinin iş sağlığı ve güvenliği algısının belirlenmesi amacıyla tanımlayıcı olarak yapıldı.

\section{B. Araştırmanın Yapıldığı Yer ve Özellikleri}

Araştırma Nisan 2017 ve Eylül 2017 tarihleri arasında İstanbul ilinde faaliyet gösteren özel bir sağllk grubu hastanelerinin ameliyathanelerinde çalışan sağlık personelinden, araştırmayı kabul eden sağlık personelinden yazılı ve sözlü izinler alındıktan sonra yapıldı.

\section{Araştırmanın Evreni ve Örneklem Seçimi}

$\mathrm{Bu}$ araştırmanın evrenini İstanbul ilinde faaliyet gösteren özel bir sağlık grubu hastanelerinin ameliyathanelerinde çalışan 245 sağlık personelinden, araştırmayı kabul eden 205 sağlık personeli oluşturdu. Araştırmayı kabul eden sağlık personelinin tamamı örneklemi oluşturarak, gönüllülük esas alındı.

\section{Veri Toplama Araçları}

Araştırmanın verileri ilgili kurumlardan izin alındıktan sonra çalışanlara ait "Sosyo-Demografik Veri Formu" ve "Hastanede Çalışan Sağlık Personeli İçin İş Güvenliği Ölçeği” ile toplandı.

\section{E. Çalışanlara Ait Sosyo Demografik Veri Formu}

Ameliyathanelerde çalışan sağlık personelinden araştırmayı kabul eden gönüllülerin, yaş, cinsiyet, medeni durumu, eğitim durumu, çalışma türü, mesleki deneyimi, pozisyonu, sosyo-ekonomik durumu, iş güvenliği eğitimi alıp almadığı, çalışma ortamında meslek hastalığı ve iş kazası geçirip geçirmediği, iş kazası geçirdi ise toplam sayısı ve çalş̧an güvenliği ile ilişkili olarak uygulamalardan memnun olup olmadığı ile ilgili toplam 14 sorudan oluşan anket formudur.

\section{F. Hastanede Çalışan Sağlık Personeli İçin İş Güvenliği Ölçeği}

Ölçek, Öztürk ve Babacan tarafından 2012 yllında geliştirilmiş, geçerlilik ve güvenirliğini 2010 yllında Trab- 
zon il merkezinde 5 ve ilçelerinde 11 devlet hastanesinde çalışan toplamda 1450 sağlık personeli üzerinde yapılmıştır [13]. Hastanelerde çalışan sağlık personelinin iş güvenliği durumunun değerlendirmesi ve sağlık personelinin iş güvenliği algılarının ölçülebilmesi amacıyla geliştirilmiş bir ölçektir. 6'lı değerlendirmeye sahip Likert tipinde bir ölçek olup, maddeler "6" tamamen katılıyorum ile "1" kesinlikle katılmıyorum arasında değerlendirilmiş toplam 45 olumlu maddeden oluşmaktadır. Puan ortalamasının 6'ya yakın puan alınması katılımcıların iş güvenliği algısının yüksek olduğunu, 1'e yakın puan alınması ise iş güvenliği algısının düşük olduğunu belirlemektedir. Ölçeğin Cronbach alfa katsayısı 0.96 olarak yüksek bulunmuş, araştırmamızda da aynı şekilde 0.96 olarak yüksek bulunmuştur.

Ölçeğin, "Mesleki Hastalıklar ve Şikâyetler”, "Sağlık Taraması ve Kayıt Sistemleri”, "Kazalar ve Zehirlenmeler”, "Yönetsel Destek ve Yaklaşımlar”, "Malzeme, Araç ve Gereç Denetimi”, "Koruyucu Önlemler ve Kurallar" ve "Fiziksel Ortam Uygunluğu” başlı̆̆ında 7 alt faktörü bulunmaktadır.

\section{G. Verilerin Toplanması}

Veri toplamadan önce ameliyathanelerde çalışan sağlık personeli ile konuşularak araştırmanın amacı anlatıldı ve veri formlarının nasıl uygulanacağı konusunda bilgi verildikten sonra formlar dağıtılarak doldurulması sağlandı.

\section{H. Verilerin Değerlendirilmesi}

Elde edilen veriler SPSS 21.0 paket programı kullanılarak istatistiksel olarak analiz edildi. Araştırmaya katılan sağlık personelinin fiziksel özellikleri frekans ve yüzde dağılımı ile sunuldu. Sağlık personelinin HİGÖ’ne ilişkin görüşlerini belirlemek amacı ile yüzde dağılımının yanı sıra aritmetik ortalama ve standart sapma değerleri kullanıldı. Ölçek karşılaştırmalarında t test, Anova ve HİGÖ’nin normal dağılım gösterip göstermediği Kolmogorov-Smirnov testi ile değerlendirildi.

\section{Araştırmanın Etik Yönü}

Medipol Üniversitesi Etik Kurulundan 08/03/2017 tarih ve 82 karar numarası ile Etik Kurul Onayı ve Kurum İzni alındıktan sonra çalışmaya başlanmıştır.

\section{BULGULAR}

Araştırmaya katılan sağlık personelinin yaş ortalaması $30,50 \pm 8,57$ olup, \%33,7’sinin 23-29 yaş grubunda olduğu, \%75,1'inin kadın, \%50,2'sinin evli, \%37,1'inin ön lisans mezunu olduğu, \%68,3'ünün gündüz ağırlıklı çalıştığı, \%36,0'ının 1-5 yıl arasında mesleki deneyime sahip olduğu, \%30,8'inin hemşire olarak görev yaptığı, \% 71,7'sinin gelirinin orta düzeyde olduğu görüldü. Ayrıca araştırmaya katılan sağlık personelinin \%89,8'i çalışan güvenliği eğitimine katıldığını ve \%35,6’sı çalışan güvenliği ile ilgili bilgileri hizmet içi eğitimden elde ettiğini belirtti (Tablo 1).

Araştırmaya katılan sağlık personelinin \%65,9'u meslek hastalığı geçirmediğini belirtirken, kas-eklem hastalıkları ve cilt hastalıkları en sık geçirilen meslek hastalıkları olarak belirlendi. Sağlık personelinin \%49,3’ü iş kazası/ yaralanması geçirmediğini belirtirken, yumuşak doku travması, kronik yorgunluk ile bel, kas ve eklem yaralanmaları en sık rastlanan iş kazası/yaralanması olarak belirlendi. Sağlık personelinin \%48,3'ünün meslek hastalığg ve iş kazas1/yaralanması geçirmediği, \%28,3'ünün 1-4 defa ve \% 23,4’ünün 5 ve üzerinde geçirdiği saptandı (Tablo 2).

Araştırmaya katılan sağlık personelinin çalışan güvenliği ile ilgili kurum uygulamalarından en fazla; bulunduğu birimde çalışıyor olmaktan, kullanılan sarf malzemelerin kalitesinden ve kullanılan araç-gereçlerden memnun oldukları görülürken, en fazla memnun olmadıkları uygulamalar 
Tablo 1: Sağlık Personelinin Tanıtıcı Özelliklerinin ve Çalışma Durumlarının Dağılımı (N=205)

\begin{tabular}{|c|c|c|}
\hline Özellikler & $\mathbf{N}$ & $\%$ \\
\hline \multicolumn{3}{|l|}{ Yaş Grupları $(30,50 \pm 8,57)(19-57$ Aralığı) } \\
\hline 22 yaş ve alt & 44 & 21,5 \\
\hline 23-31 yaş & 77 & 37,6 \\
\hline $32-40$ yaş & 55 & 26,8 \\
\hline 41 yaş ve üzeri & 29 & 14,1 \\
\hline \multicolumn{3}{|l|}{ Cinsiyet } \\
\hline Kadın & 154 & 75,1 \\
\hline Erkek & 51 & 24,9 \\
\hline \multicolumn{3}{|l|}{ Medeni Durum } \\
\hline Evli & 103 & 50,2 \\
\hline Bekâr & 102 & 49,8 \\
\hline \multicolumn{3}{|l|}{ Eğitim Durumu } \\
\hline İlköğretim & 22 & 10,7 \\
\hline Lise & 49 & 23,9 \\
\hline Ön Lisans & 76 & 37,1 \\
\hline Lisans & 33 & 16,1 \\
\hline Lisansüstü & 25 & 12,2 \\
\hline \multicolumn{3}{|l|}{ Çalışma Türü } \\
\hline Gündüz ağırıklı & 140 & 68,3 \\
\hline Gece ağırlıkıı & 65 & 31,7 \\
\hline \multicolumn{3}{|l|}{ Mesleki Deneyim } \\
\hline 1 yıldan az & 45 & 22,0 \\
\hline $1-5 \mathrm{yll}$ & 74 & 36,0 \\
\hline 6-10 yıl & 43 & 21,0 \\
\hline 11 yıl ve üzeri & 43 & 21,0 \\
\hline \multicolumn{3}{|l|}{ Pozisyon } \\
\hline Hekim & 24 & 11,7 \\
\hline Hemşire & 63 & 30,8 \\
\hline Yardımcı Sağlık Personeli & 49 & 23,9 \\
\hline Cerrahi Tekniker & 47 & 22,9 \\
\hline Diğer (Anestezi Teknisyeni, Tıbbi Sekreter) & 22 & 10,7 \\
\hline \multicolumn{3}{|l|}{ Gelir Durumu } \\
\hline Düşük & 30 & 14,6 \\
\hline Orta & 147 & 71,7 \\
\hline Yüksek & 28 & 13,7 \\
\hline \multicolumn{3}{|l|}{ Çalışan Güvenliği Eğitimine Kattım } \\
\hline Var & 184 & 89,8 \\
\hline Yok & 21 & 10,2 \\
\hline \multicolumn{3}{|l|}{ Çalışan Güvenliği ile İlgili Bilgi Kaynakları } \\
\hline Katılmadım & 21 & 102 \\
\hline Okul eğitimi & 34 & 16,6 \\
\hline Seminer, kurs, kongre, sempozyum & 16 & 7,8 \\
\hline Uyum eğitimi & 61 & 29,8 \\
\hline Hizmet içi eğitim & 73 & 35,6 \\
\hline
\end{tabular}

ise iş yükü, çalışma saatleri/nöbetler ve hemşire sayısı olarak belirlendi (Tablo 3).

Sağlık personelinin HİGÖ'nden aldıkları puan ortalamasının 3,45 $\pm 1,00$ olduğu belirlendi. Sağlık personelinin
Tablo 2: Sağlık Personelinin Meslek Hastalığı ve İş Kazası/Yaralanması Deneyimlerinin Dağılımı (N=205)

\begin{tabular}{|c|c|c|}
\hline Özellikler & $\mathbf{N}$ & $\%$ \\
\hline \multicolumn{3}{|l|}{ Mesleki Hastalık Deneyimi* } \\
\hline Geçirmedim & 135 & 65,9 \\
\hline Sindirim sistemi hastalıkları & 27 & 13,2 \\
\hline Psiko-sosyal bozukluklar & 28 & 13,7 \\
\hline Cilt hastalıkları & 32 & 15,6 \\
\hline Kardiyo-vasküler hastalıklar & 19 & 9,3 \\
\hline Kas-eklem hastalıkları & 41 & 20,0 \\
\hline Sinir sistemi hastalıkları & 18 & 8,8 \\
\hline Enfeksiyon hastalıkları & 8 & 3,9 \\
\hline \multicolumn{3}{|l|}{ İş Kazası/Yaralanması Deneyimi* } \\
\hline Geçirmedim & 101 & 49,3 \\
\hline Yumuşak doku travması & 80 & 39,0 \\
\hline Bel kas ve eklem yaralanmaları & 43 & 21,0 \\
\hline Elektrik çarpmaları ve yanıklar & 10 & 4,9 \\
\hline Kayma/düşme vb. travmalar & 33 & 16,1 \\
\hline Zehirlenmeler & 11 & 5,4 \\
\hline Fiziksel şiddete maruz kalma & 6 & 2,9 \\
\hline Sözel şiddete maruz kalma & 20 & 9,8 \\
\hline Psikolojik şiddete maruz kalma & 27 & 13,2 \\
\hline Duygusal sorunlar & 30 & 14,6 \\
\hline Kronik yorgunluk & 57 & 27,8 \\
\hline \multicolumn{3}{|c|}{$\begin{array}{l}\text { Mesleki Hastalık ve İş Kazası/Yaralanması } \\
\text { Deneyim Sayısı }\end{array}$} \\
\hline Hiç geçirmedim & 99 & 48,3 \\
\hline 1-4 defa & 58 & 28,3 \\
\hline 5 ve üzeri & 48 & 23,4 \\
\hline
\end{tabular}

HİGÖ'nin alt boyutları arasında en yüksek üç puan ortalamasını aldıkları alt boyutların "Koruyucu Önlemler ve Kurallar $(4,33 \pm 1,41)$ ", "Fiziksel Ortam Uygunluğu (4,12 $\pm 1,48)$ " ve Malzeme ve Araç Denetimi $(4,07 \pm 1,50)$ " olduğu görüldü. En düşük puan ortalamasını aldıkları alt boyutun ise "Yönetsel Destek ve Yaklaşımlar (3,16 \pm 1,29)" olduğu saptandı (Tablo 4).

Sağlık personelinin tanıtıcı özellikleri ile HİGÖ’nden aldıkları puan ortalamaları karşılaştırıldığında; cinsiyetlerin puan ortalamaları arasında istatistiksel olarak anlamlı fark olduğu saptanmıştır $(\mathrm{p}<0,05)$. Erkek katılımcıların aldıkları puan ortalaması, kadın katılımciların aldıkları puan ortalamasından istatistiksel olarak anlamlı derecede yüksek bulunmuştur (Tablo 5).

Sağlık personelinin yaş grupları, medeni durumları ve eğitim durumları ile HİGÖ’nden aldıkları puan ortalama- 
Tablo 3: Sağlık Personelinin Çalışan Güvenliği ile İlgili Kurum Uygulamalarından Memnuniyetlerinin Dağılımı $(\mathrm{N}=205)$

\begin{tabular}{|c|c|c|c|c|}
\hline \multirow[t]{2}{*}{ Özellikler } & \multicolumn{2}{|c|}{ Memnunum } & \multicolumn{2}{|c|}{$\begin{array}{l}\text { Memnun } \\
\text { değilim }\end{array}$} \\
\hline & $\mathbf{N}$ & $\%$ & $\mathbf{N}$ & $\%$ \\
\hline Çalışma saatleri/nöbetler & 97 & 47,3 & 108 & 52,7 \\
\hline Görev dağılımı & 116 & 56,6 & 89 & 43,4 \\
\hline İş yükü & 86 & 42,0 & 119 & 58,0 \\
\hline İş hızı & 101 & 49,3 & 104 & 50,7 \\
\hline Hemşire sayısı & 109 & 53,2 & 96 & 46,8 \\
\hline Hekim sayısı & 154 & 75,1 & 51 & 24,9 \\
\hline Hasta sayısı & 134 & 65,4 & 71 & 34,6 \\
\hline $\begin{array}{l}\text { Çalışma ortamının donanımı ve } \\
\text { dizaynı }\end{array}$ & 137 & 66,8 & 68 & 33,2 \\
\hline $\begin{array}{l}\text { Çalışma ortamında kişiler arası } \\
\text { ilişkiler }\end{array}$ & 129 & 62,9 & 76 & 37,1 \\
\hline Kullanılan araç-gereç & 162 & 79,0 & 43 & 21,0 \\
\hline $\begin{array}{l}\text { Kullanılan temizlik malzemelerinin } \\
\text { kalitesi }\end{array}$ & 158 & 77,1 & 47 & 22,9 \\
\hline $\begin{array}{l}\text { Kullanılan sarf malzemelerin } \\
\text { kalitesi }\end{array}$ & 163 & 79,5 & 42 & 20,5 \\
\hline $\begin{array}{l}\text { Kişisel koruyucu malzemelerin } \\
\text { kalitesi }\end{array}$ & 155 & 75,6 & 50 & 24,4 \\
\hline Bu kurumda çalışıyor olmaktan & 152 & 74,1 & 53 & 25,9 \\
\hline Bu birimde çalışıyor olmaktan & 164 & 80,0 & 41 & 20,0 \\
\hline Sağlık güvenliği önlemleri & 154 & 75,1 & 51 & 24,9 \\
\hline $\begin{array}{l}\text { Çalışan sağlık ve güvenlik } \\
\text { politikaları }\end{array}$ & 140 & 68,3 & 65 & 31,7 \\
\hline Hasta kaldırma/taşıma sistemleri & 134 & 65,4 & 71 & 34,6 \\
\hline $\begin{array}{l}\text { Çalışan güvenliğine yönelik } \\
\text { önlemler }\end{array}$ & 145 & 70,7 & 60 & 29,3 \\
\hline Güvenlik personeli davranışları & 145 & 70,7 & 60 & 29,3 \\
\hline $\begin{array}{l}\text { İş kazası/meslek hastalı̆ı } \\
\text { durumunda kurumun sorumluluk } \\
\text { alması/desteği }\end{array}$ & 139 & 67,8 & 66 & 32,2 \\
\hline
\end{tabular}

ları arasında istatistiksel olarak anlamlı farklılık saptanmamıştır (Tablo 5).

Araştırmaya katılan sağlık personelinin çalışma durumları ile HİGÖ'nden aldıkları puan ortalamaları karşılaşııııldığında; sağlık personelinin çalışma türü ile HİGÖ'nden aldıkları puan ortalamaları arasında istatistiksel anlamlı fark olduğu saptanmıştır $(p<0,01)$. Gündüz ağırlıklı çalışan
Tablo 4: Sağlık Personelinin Hastanelerde İş Güvenli-

\begin{tabular}{lcc}
\hline Ölçek ve Alt Boyutları & Ort. \pm SS. & $\begin{array}{c}\text { Min. - Max. } \\
\text { Değerler }\end{array}$ \\
\hline Mesleki Hastalıklar ve Şikâyetler & $2,65 \pm 1,10$ & $1-6$ \\
Sağlık Taraması ve Kayıt Sistemi & $3,87 \pm 1,29$ & $1-6$ \\
Kazalar ve Zehirlenmeler & $3,36 \pm 1,37$ & $1-6$ \\
Yönetsel Destek ve Yaklaşımlar & $3,16 \pm 1,29$ & $1-6$ \\
Malzeme ve Araç Denetimi & $4,07 \pm 1,50$ & $1-6$ \\
Koruyucu Önlemler ve Kurallar & $4,33 \pm 1,41$ & $1-6$ \\
Fiziksel Ortam Uygunluğu & $4,12 \pm 1,48$ & $1-6$ \\
TOPLAM & $\mathbf{3 , 4 5} \pm 1,00$ & $1-5,91$ \\
\hline
\end{tabular}

Tablo 5: Sağlık Personelinin Tanıtıcı Özellikleri ile Hastanelerde İş Güvenliği Ölçeğinden Aldıkları Puan Ortalamasının Karşılaş̧ırılması ( $\mathrm{N}=205)$

\begin{tabular}{llc}
\hline Özellikler & Ort. \pm SS. & Test ve $\mathbf{p ~ D e g ̆ e r i ~}$ \\
\hline Yaş Grupları * & & \\
22 yaş ve alt & $3,62 \pm 0,99$ & $\mathrm{~F}=1,459$ \\
$23-31$ yaş & $3,29 \pm 0,97$ & $\mathrm{p}=0,227$ \\
$32-40$ yaş & $3,43 \pm 1,09$ & \\
41 yaş ve üzeri & $3,64 \pm 0,89$ & \\
\hline Cinsiyet ** & & $\mathrm{t}=-2,141$ \\
Kadın & $3,36 \pm 0,96$ & $\mathrm{p}=0,033$ \\
Erkek & $3,71 \pm 1,10$ & \\
\hline Medeni Durum** & & $\mathrm{t}=-0,157$ \\
Evli & $3,44 \pm 1,04$ & $\mathrm{p}=0,875$ \\
Bekâr & $3,46 \pm 0,97$ & \\
\hline Eğitim Durumu* & & $\mathrm{F}=1,742$ \\
İlköğretim & $3,63 \pm 1,04$ & $\mathrm{p}=0,142$ \\
Lise & $3,50 \pm 1,15$ & \\
Ön Lisans & $3,57 \pm 0,95$ & \\
Lisans & $3,25 \pm 0,95$ & \\
Lisansüstü & $3,07 \pm 0,80$ & \\
\hline *: Tek yönlü varyans analizi & $* *:$ Bağımsı gruplarda t-testi &
\end{tabular}

personelin aldıkları puan ortalaması, gece ağırlıklı çalışan personelin aldıkları puan ortalamasından istatistiksel olarak anlamlı derecede yüksek bulunmuştur (Tablo 6).

Sağlık personelinin mesleki deneyim süreleri ile HİGÖ'nden aldıkları puan ortalamaları arasında istatistiksel olarak anlamlı fark olduğu saptanmıştır $(\mathrm{p}<0,05) .1$ yıldan az mesleki deneyime sahip olan personelin aldıkları puan ortalaması, 1-5 yil ve 6-10 yll mesleki deneyime sahip 
olan personelin aldıkları puan ortalamasından istatistiksel olarak anlamlı derecede yüksek bulunmuştur (Tablo 6).

Sağllk personelinin gelir düzeyleri ile HİGÖ'nden aldıkları puan ortalamaları arasında ileri düzeyde anlamlı fark olduğu saptanmıştır $(\mathrm{p}<0,01)$. Orta gelir düzeyine sahip olan personelin aldıkları puan ortalaması, düşük ve yüksek gelir düzeyine sahip olan personelin aldıkları puan ortalamasından ileri düzeyde anlamlı derecede yüksek bulunmuştur (Tablo 6).

Sağlık personelinin pozisyonu ile HİGÖ'nden aldıkları puan ortalamaları arasında istatistiksel olarak anlamlı farklılık saptanmamıştır (Tablo 6).

Tablo 6: Sağlık Personelinin Çalışma Durumları ile Hastanelerde İş Güvenliği Ölçeğinden Aldıkları Puan Ortalamasının Karşılaştırılması ( $\mathrm{N}=205)$

\begin{tabular}{|c|c|c|}
\hline Özellikler & Ort. \pm SS. & Test ve $p$ Değeri \\
\hline \multicolumn{3}{|l|}{ Çalışma Türü** } \\
\hline Gündüz ağırlıklı & $3,56 \pm 0,98$ & $t=2,253$ \\
\hline Gece ağırlıklı & $3,22 \pm 1,01$ & $p=0,025$ \\
\hline \multicolumn{3}{|c|}{ Mesleki Deneyim* } \\
\hline 1 yıldan az ${ }^{a}$ & $3,80 \pm 0,92$ & $F=3,053$ \\
\hline $1-5$ yıl $^{\mathrm{b}}$ & $3,31 \pm 1,05$ & $p=0,028$ \\
\hline $6-10 \mathrm{yll}^{\mathrm{c}}$ & $3,24 \pm 0,95$ & $a>b, c$ \\
\hline 11 yıl ve üzeri ${ }^{d}$ & $3,52 \pm 0,97$ & \\
\hline \multicolumn{3}{|l|}{ Pozisyon* } \\
\hline Hekim & $3,27 \pm 0,81$ & $F=0,905$ \\
\hline Hemşire & $3,32 \pm 1,03$ & $p=0,462$ \\
\hline Personel & $3,59 \pm 1,08$ & \\
\hline Tekniker & $3,46 \pm 0,97$ & \\
\hline Diğer & $3,65 \pm 1,02$ & \\
\hline \multicolumn{3}{|l|}{ Gelir Durumu* } \\
\hline Düşük ${ }^{a}$ & $3,09 \pm 1,13$ & $F=6,602$ \\
\hline Ortab $^{b}$ & $3,60 \pm 0,99$ & $p=0,002$ \\
\hline Yüksek ${ }^{c}$ & $3,02 \pm 0,69$ & $b>a, c$ \\
\hline
\end{tabular}

Araştırmaya katılan sağlık personelinin meslek hastalığ ve iş kazası/yaralanması deneyimleri ile HİGÖ'nden aldıkları puan ortalamaları karşılaştırıldığında; meslek hastalığı geçirme durumlarının puan ortalamaları arasında istatistiksel olarak anlamlı fark olduğu saptanmıştır $(\mathrm{p}<0,05)$. Mes- lek hastalığı geçirmeyen personelin aldıkları puan ortalaması, meslek hastalığı geçiren personelin aldıkları puan ortalamasından istatistiksel olarak anlamlı derecede yüksek bulunmuştur (Tablo 7).

Sağlık personelinin meslek hastalığı ve iş kazası/ yaralanması deneyim sayıları ile HİGÖ'nden aldıkları puan ortalamaları arasında çok ileri düzeyde anlamlı fark olduğu saptanmıştır $(\mathrm{p}<0,001) .5$ ve üzerinde deneyime sahip olan personelin aldıkları puan ortalaması, hiç deneyimi olmayan personelin aldıkları puan ortalamasından ileri düzeyde $(\mathrm{p}<0,01)$ ve $1-4$ defa deneyimi olan personelin aldıkları puan ortalamasından çok ileri düzeyde $(\mathrm{p}<0,001)$ anlamlı derecede düşük bulunmuştur (Tablo 7)

Sağlık personelinin iş kazası/yaralanması deneyimi ile HİGÖ’nden aldıkları puan ortalamaları arasında istatistiksel olarak anlamlı farklılık saptanmamıştır (Tablo 7).

Tablo 7: Sağlık Personelinin Meslek Hastalığı ve İş Kazası/Yaralanması Deneyimleri ile Hastanelerde İş Güvenliği Ölçeğinden Aldıkları Puan Ortalamasının Karşılaştırılması $(\mathrm{N}=205)$

\begin{tabular}{|c|c|c|}
\hline Özellikler & Ort. \pm SS. & $\begin{array}{l}\text { Test ve p } \\
\text { Değeri }\end{array}$ \\
\hline \multicolumn{3}{|c|}{ Meslek Hastalığı Deneyimi* } \\
\hline Geçirmedim & $3,55 \pm 0,95$ & $t=2,019$ \\
\hline Geçirdim & $3,25 \pm 1,07$ & $p=0,045$ \\
\hline \multicolumn{3}{|c|}{ İş Kazası/Yaralanması Deneyimi* } \\
\hline Geçirmedim & $3,56 \pm 0,91$ & $t=1,596$ \\
\hline Geçirdim & $3,34 \pm 1,08$ & $p=0,112$ \\
\hline \multicolumn{3}{|c|}{$\begin{array}{l}\text { Meslek Hastalığı ve İş Kazası/ } \\
\text { Yaralanması Deneyim Sayısı** }\end{array}$} \\
\hline Hiç geçirmedim ${ }^{a}$ & $3,55 \pm 0,91$ & $F=10,225$ \\
\hline $1-4$ defa $^{b}$ & $3,71 \pm 1,04$ & $p=0,000$ \\
\hline 5 ve üzeri ${ }^{c}$ & $2,91 \pm 0,95$ & $c<a, b$ \\
\hline
\end{tabular}

*: Bağımsız gruplarda t-testi $\quad$ **: Tek yönlü varyans analizi

Araştırmaya katılan sağlık personelinin çalışan güvenli ile ilgili kurum uygulamalarından memnuniyetleri ile HİGÖ’nden aldıkları puan ortalamaları karşılaştırıldığında; çalışma saatleri/nöbetler, görev dağılımı, iş yükü, iş hızı, hasta sayısı, çalışma ortamında kişiler arası ilişkiler, kullanı- 
lan araç-gereç, kullanılan temizlik malzemelerinin kalitesi, kullanılan sarf malzemelerin kalitesi, kişisel koruyucu malzemelerin kalitesi, bağlı bulunduğu kurumda ve birimde çalışıyor olmaktan, sağlık güvenliği önlemleri, çalışan sağlık ve güvenlik politikaları, hasta kaldırma/taşıma sistemleri, çalışan güvenliğine yönelik önlemler, güvenlik personeli davranışları ve iş kazası/meslek hastalığı durumunda kurumun sorumluluk almasından memnun olmayan personelin aldıkları puan ortalaması, memnun olan personelin aldıklar1 puan ortalamasından çok ileri düzeyde anlamlı derece düşük bulunmuştur $(\mathrm{p}<0,001)$. Hemşire sayısı, hekim sayısı ve çalışma ortamının donanımı ve dizaynından memnun olmayan personelin aldıkları puan ortalamaları, memnun olan personelin aldıkları puan ortalamasından ileri düzeyde $(\mathrm{p}<0,01)$ anlamlı derecede düşük bulunmuştur (Tablo 8).

\section{TARTIŞMA}

Araştırmamıza katılan sağlık personelinde en fazla görülen meslek hastalığı \%20 ile kas- eklem hastalıları olduğu belirlenmiş olup, aynı şekilde literatüre bakıldığında Castro v.d.'nin Finlandiya'da sağlık çalışanlarına yönelik yapmış oldukları bir çalışmada da benzer şekilde olduğu görülmüştür [14]. Sağlık personelinin en fazla geçirdikleri iş kazası ise \%39 ile yumuşak doku travması olduğu belirlenmiş, literatüre bakıldığında Clarke v.d.'nin Amerika Birleşik Devletleri ve Kanada'da yaptıkları bir araştırmada delici kesici alet yaralanmalarının fazla olduğu görülmüştür [15].

Araştırmamızda ameliyathanede çalışan sağlık personelinin HİGÖ’nden aldıkları puan ortalamalarına bakıldığında 3,45 $\pm 1,00$ olarak belirlenmiştir. Ölçekteki en az puan " 1 ", en fazla ise "6" puan olarak hesaplandığında çalışanların iş güvenliğinin orta düzeyde olduğu belirlendi. Karaer v.d.'nin İzmir ilinde bir devlet hastanesinde sağlık personeline yönelik yapmış oldukları çalışmada ölçek toplamında iş güvenliğinin orta düzeyde sağlandığı $(3,47 \pm 0,72)$ [16],

Tablo 8: Sağlık Personelinin Çalışan Güvenliği ile İlgili Kurum Uygulamalarından Memnuniyetleri ile Hastanelerde İş Güvenliği Ölçeğinden Aldıkları Puan Ortalamasının Karşılaştırılması ( $\mathrm{N}=205)$

\begin{tabular}{|c|c|c|c|}
\hline \multirow[b]{2}{*}{ Özellikler* } & \multicolumn{2}{|c|}{ Ort. \pm SS. } & \multirow{2}{*}{$\begin{array}{l}\text { Test ve } p \\
\text { Değeri }\end{array}$} \\
\hline & Memnunum & $\begin{array}{l}\text { Memnun } \\
\text { Değilim }\end{array}$ & \\
\hline Çalışma saatleri/nöbetler & $3,89 \pm 0,85$ & $3,05 \pm 0,97$ & $\begin{array}{l}t=6,464 \\
p=0,000\end{array}$ \\
\hline Görev dağılımı & $3,76 \pm 0,93$ & $3,04 \pm 0,95$ & $\begin{array}{l}t=5,475 \\
p=0,000\end{array}$ \\
\hline İş yükü & $3,88 \pm 0,90$ & $3,13 \pm 0,96$ & $\begin{array}{l}t=5,635 \\
p=0,000\end{array}$ \\
\hline İş hızı & $3,78 \pm 0,90$ & $3,13 \pm 1,00$ & $\begin{array}{l}t=4,905 \\
p=0,000\end{array}$ \\
\hline Hemşire sayısı & $3,66 \pm 1,03$ & $3,21 \pm 0,92$ & $\begin{array}{l}t=3,311 \\
p=0,001\end{array}$ \\
\hline Hekim sayısı & $3,58 \pm 1,00$ & $3,06 \pm 0,93$ & $\begin{array}{l}t=3,216 \\
p=0,002\end{array}$ \\
\hline Hasta sayısı & $3,64 \pm 0,98$ & $3,08 \pm 0,95$ & $\begin{array}{l}t=3,896 \\
p=0,000\end{array}$ \\
\hline $\begin{array}{l}\text { Çalışma ortamının donanımı } \\
\text { ve dizaynı }\end{array}$ & $3,61 \pm 0,94$ & $3,12 \pm 1,05$ & $\begin{array}{l}t=3,365 \\
p=0,001\end{array}$ \\
\hline $\begin{array}{l}\text { Çalışma ortamında kişiler } \\
\text { arası ilişkiler }\end{array}$ & $3,71 \pm 0,92$ & $3,01 \pm 0,99$ & $\begin{array}{l}t=5,057 \\
p=0,000\end{array}$ \\
\hline Kullanılan araç-gereç & $3,65 \pm 0,92$ & $2,70 \pm 0,95$ & $\begin{array}{l}t=5,961 \\
p=0,000\end{array}$ \\
\hline $\begin{array}{l}\text { Kullanılan temizlik } \\
\text { malzemelerinin kalitesi }\end{array}$ & $3,66 \pm 0,89$ & $2,74 \pm 1,04$ & $\begin{array}{l}t=5,906 \\
p=0,000\end{array}$ \\
\hline $\begin{array}{l}\text { Kullanılan sarf malzemelerin } \\
\text { kalitesi }\end{array}$ & $3,62 \pm 0,92$ & $2,78 \pm 1,04$ & $\begin{array}{l}t=5,087 \\
p=0,000\end{array}$ \\
\hline $\begin{array}{l}\text { Kişisel koruyucu } \\
\text { malzemelerin kalitesi }\end{array}$ & $3,64 \pm 0,91$ & $2,85 \pm 1,04$ & $\begin{array}{l}t=5,099 \\
p=0,000\end{array}$ \\
\hline $\begin{array}{l}\text { Bu kurumda çalışıyor } \\
\text { olmaktan }\end{array}$ & $3,65 \pm 0,90$ & $2,86 \pm 1,04$ & $\begin{array}{l}t=5,289 \\
p=0,000\end{array}$ \\
\hline $\begin{array}{l}\text { Bu birimde çalışıyor } \\
\text { olmaktan }\end{array}$ & $3,59 \pm 0,93$ & $2,90 \pm 1,11$ & $\begin{array}{l}t=4,079 \\
p=0,000\end{array}$ \\
\hline Sağlık güvenliği önlemleri & $3,65 \pm 0,92$ & $2,85 \pm 1,00$ & $\begin{array}{l}t=5,225 \\
p=0,000\end{array}$ \\
\hline $\begin{array}{l}\text { Çalışan sağlık ve güvenlik } \\
\text { politikaları }\end{array}$ & $3,74 \pm 0,88$ & $2,82 \pm 0,97$ & $\begin{array}{l}t=6,690 \\
p=0,000\end{array}$ \\
\hline $\begin{array}{l}\text { Hasta kaldırma/taşıma } \\
\text { sistemleri }\end{array}$ & $3,75 \pm 0,87$ & $2,88 \pm 0,99$ & $\begin{array}{l}t=6,428 \\
p=0,000\end{array}$ \\
\hline $\begin{array}{l}\text { Çalışan güvenliğine yönelik } \\
\text { önlemler }\end{array}$ & $3,69 \pm 0,89$ & $2,85 \pm 1,01$ & $\begin{array}{l}t=5,873 \\
p=0,000\end{array}$ \\
\hline $\begin{array}{l}\text { Güvenlik personeli } \\
\text { davranışları }\end{array}$ & $3,63 \pm 0,95$ & $3,01 \pm 1,00$ & $\begin{array}{l}t=4,160 \\
p=0,000\end{array}$ \\
\hline $\begin{array}{l}\text { İş kazası/meslek hastalığı } \\
\text { durumunda kurumun } \\
\text { sorumluluk alması/desteği }\end{array}$ & $3,70 \pm 0,88$ & $2,91 \pm 1,03$ & $\begin{array}{l}t=5,630 \\
p=0,000\end{array}$ \\
\hline
\end{tabular}


Öztürk v.d.'nin Trabzon ilinde bulunan devlet hastanelerinde sağlık personelleriyle yapmış oldukları çalışmalarda ise ölçek toplamında iş güvenliğinin yeterli düzeyde sağlandığı $(4,05 \pm 1,01)$ görülmüştür [13].

Sağlık personelinin tanıtıcı özellikleri ile HİGÖ'nden aldıkları puan ortalamaları karşılaştırıldığında; erkek personelin aldıkları puan ortalaması, kadın personelin aldıkları puan ortalamasından istatistiksel olarak anlamlı derecede yüksek bulundu. Kılıç̧ın çalışmasında erkek personelin aldıkları iş güvenliği puan ortalamaları, kadın personelin aldıkları iş güvenliği puan ortalamalarından yüksek olduğu ve aralarındaki farkın istatistiksel olarak anlamlı bulunduğu görüldü [17]. Erkek personelin kadın personelden daha doyumlu olmaları, memnuniyet düzeylerinin yüksek olması ve teknik konularda bakış açılarının daha iyi olmasından kaynaklandığını düşünmekteyiz.

Araştırmamızda sağlık personelinin mesleki deneyim süreleri ile HİGÖ’nden aldıkları puan ortalamalarına bakıldığında; 1 yıldan az mesleki deneyime sahip olan personelin aldıkları puan ortalaması, 1-5 yıl ve 6-10 yıl mesleki deneyime sahip olan personelin aldıkları puan ortalamasından istatistiksel olarak anlamlı derecede yüksek bulundu. 1 yıldan az ve 11 yildan fazla deneyime sahip olan personelin iş güvenliğine algılarının daha fazla olduğu belirlendi. Çalışmamız da çalışma yılı 1 yıl ve altı olan sağlık personelinin yüksek puan almasını çalışma yaşamında henüz yeni olmalarına, çalışma yılı 11 yıl ve üzeri olan sağlık personelinin yüksek puan almasını ise çalışma yılı artıkça, alınması gereken güvenlik önlemleri hakkında tecrübeye sahip olmalarına ve çalışıkları birimde daha rahat bir pozisyonda çalışıyor olabileceklerine bağlayabiliriz. Çalışmamızı destekleyen araştırma bulunmaktadır [18].

Araştırmamızda sağlık personelinin meslek hastalığı ve iş kazası/yaralanması deneyimleri ile HİGÖ'nden aldıkları puan ortalamaları karşılaştırıldığında; meslek hastalığı geçirmeyen personelin aldıkları puan ortalaması, geçiren personelin aldıkları puan ortalamasından istatistiksel olarak anlamlı derecede yüksek bulundu. Meslek hastalı̆̆ geçirmeyen personelin iş güvenliği konusunda daha ilgili oldukları belirlenmiştir. Bu durum, meslek hastalığı geçiren personelin yaşadıkları olumsuz deneyim nedeni ile çalıştıkları kurumlarını güvenli olarak değerlendirmedikleri düşünülmektedir. Çalışmamızı destekleyen araşıırma bulunmaktadır [17].

Araştırmamıza katılan sağlık personelinin meslek hastalığı ve iş kazası/yaralanması deneyim sayıları ile HİGÖ'nden aldıkları puan ortalamalarına bakıldığında 5 ve üzerinde deneyime sahip olan personelin aldıkları puan ortalaması, hiç deneyimi olmayan personelin aldıkları puan ortalamasından ileri düzeyde $(\mathrm{p}<0,01)$ ve $1-4$ defa deneyimi olan personelin aldıkları puan ortalamasından çok ileri düzeyde $(\mathrm{p}<0,001)$ anlamlı derecede düşük bulundu. Çalışmamız personelin iş kazası geçirdikçe algısının azaldığını destekler niteliktedir. Çalışanların iş kazası geçirmesi motivasyonunu ve dikkatini etkilediğinden, çok fazla iş kazası geçiren çalışanların algısının azaldığı ve bundan dolayı kazaya olan eğiliminin arttığı düşünülmektedir.

\section{SONUÇ VE ÖNERILER}

Ameliyathanelerde Çalışan Sağlık Personelinin İş Sağllğı ve Güvenliği Algısının Belirlenmesi amacıyla yapılan bu araştırmada aşağıdaki sonuçlar elde edilmiştir.

Çalışmada sağlık personelinin HİGÖ'nden aldıkları puan ortalamasının $3,45 \pm 1,00$ olduğu belirlenmiş olup, cinsiyet, çalışma türü, mesleki deneyim süreleri, gelir düzeyi, meslek hastalığı deneyimleri, meslek hastalığı ve iş kazası/yaralanması deneyim sayıları, memnuniyet durumları ile HİGÖ puan ortalamaları arasında istatistiksel olarak anlamlı fark saptandı. 
Sağlık personelinin meslek hastalıkları olarak bildirdikleri kas-eklem hastalıkları, cilt hastalıkları, psiko-sosyal bozukluklara neden olan etmenlerin incelenmeli, kaseklem hastalıklarına neden olan uzun süreli ayakta çalışma süreleri ve şartları iyileştirilmeli, hasta kaldırma, çekme vb. uygulamalar için talimatlar oluşturulmalıdır.

Sağlık personelinin yorgunluk, kol ve bacak ağrıları, varis ve uykusuzluk şikayetlerinin iyileştirilmesi için çalışma alanlarında ergonomik sandalye, koltuk, seçimi ile hastaların taşınması veya kaldırılması esnasında çalışan gücü yerine yardımcı alet kullanımı yaygınlaşıııılmalıdır.

Özellikle rotasyonlu çalışma shifti oluşturulmalı ve iş yüküne göre çalışma saatleri yeniden düzenlenmeli, sürekli ayakta ve ağır işlerde çalışanlar farklı rollerde görevlendirilmelidir. Egzersiz eğitimleri verilmeli, iş yükü adaletli dağıtılmalı, gece nöbetinde çalışan kişiler için ergonomik düzenlenmiş dinlenme alanları oluşturulmalı, çalışanlar için sağlanan lojman hizmetinin de büyütülerek daha fazla kişiyi kapsayacak şekilde hastaneye yakın konumlandırılmalıdir.

Sistematik olarak ameliyathanelerde detaylı risk analizleri yapılarak değerlendirilmeli ve düzenleyici önleyici faaliyetler tespit edilmelidir.

Gelecekte yapılacak çalışmalarda, çalışanların iş sağlığı ve güvenliği konusundaki düzenlemelere yönelik bilgi düzeylerini ölçmek amacıyla daha detaylı çalışmaların yapılmasının fayda sağlayacağı düşünülmekte, ayrıca ileriki çalışmalarda, işs sağlığı ve güvenliği konusunda alınan eğitimlerle, çalışanların sağlık ve güvenlik algıları arasındaki ilişkinin incelenmesinin, literatüre katkı sağlamak açısından yararlı olacağı düşünülmektedir.

\section{KAYNAKLAR}

[1] GÜVEN, Rana, "Güvenlik kültürü oluşumunda eğitimin önemi”, $\dot{I}_{\xi}$ Sağllğg ve Güvenliği Dergisi, S.30, 2006, s.5-11.

[2] BİLİR, Nazmi; YILDIZ, Naci A, İş Sağllğı ve Güvenliği, Ankara, 2014, s.3-27.

[3] KESGIN, Coşkun; TOPUZOĞLU, Ahmet, "Sağlığın Tanımı; Başaçıkma", İKÜ Güncesi Fen ve Mühendislik Bilimleri Dergisi, S.3, 2006, s.47-49.

[4] BOSTANCI, Yalçın, "İşverenin İş Sağlığı ve Güvenliğine İlişkin Yükümlülüklerini Yerine Getirmemesi ve Yaptırımları", Selçuk Üniversitesi Hukuk Fakültesi Dergisi, 12(1-2), 2011, 67-86.

[5] YÜKSEL, Öznur; İnsan Kaynakları Yönetimi, Ankara, 2003.

[6] ALTINEL, Hüseyin, İşçi Sağlığı ve İş Güvenliği, Ankara, 2011, s.74.

[7] BİLìR, Nazmi, İş Sağlığı ve Güvenliği, Ankara, 2016, s. 15.

[8] YERZÜLCAN, Sema, v.d. "Ameliyathane Ortamında Sirküle ve Scrub Hemşire Koordinasyonunun gerekliliği ve Ameliyat Başına Gaz Sayımına Etkisi”, Istanbul Tip Dergisi, S.4, 2009, s.188.

[9] MEYDANLIOĞLU, Ayşe, "Sağlık Çalışanlarının Sağllğı ve Güvenliğı”, Balıkesir Sağllk Bilimleri Dergisi, S.3, 2013, s.192-199.

[10] TDK, "http://www.tdk.gov.tr/index.php?option= co $\mathrm{m} \_$gts\&arama $=$gts\&guid=TDK.GTS.5a2eae $406 \mathrm{~d} 802$ 9.11035462" (Erişim tarihi: 05.07.2017)

[11] NICHOLS RL; BENNETT JV; BRACHMAN PS; The operating room Hospital Infections, Boston, 1992, s.461-473.

[12] UÇAK, Hatice, Ameliyathanede Yönetim - Organizasyon \& Cerrahi Uygulamalar, 2.Baskı, İzmir, 2016, s.69.

[13] ÖZTÜRK, Havva; BABACAN, Elif; ANAHAR ÖZDAŞ, Elif, "Hastanede Çalışan Sağlık Personelinin İş Güvenliğì", Gümüşhane Üniversitesi Sağllk Bilimleri Dergisi, S.4, 2012, s.252-268.

[14] CASTRO, AB, v.d. "Occupational Health and Safety Issues Among Nurses in the Philippines" AAOHN Journal, S.4, 2009, s.149-157.

[15] CLARKE, Sean P; SCHUBERT, Maria; KÖRNER, Thorsten, "Sharp-device injuries to hospital staff nur- 
Karaelmas İs Sağlı̆̆ı ve Güvenlĭği Dergisi, Cilt 2, Sayı 2, 2018, ss. 75-85

Karaelmas Journal of Occupational Health and Safety, Vol. 2, No. 2, 2018, pp. 75-85

ses in 4 countries" Infection Control \& Hospital Epidemiology, 2007, S.4, s. 473-478.

[16] KARAER, Gönül; ÖZMEN, Dilek, "Sağlık Çalışanlarının İş Güvenliği: Devlet Hastanesi Örneği”, Türkiye Klinikleri, S.4, 2016, s.315.

[17] KILIÇ, Talip, "Bir Eğitim ve Araştırma Hastanesinde Görev Yapan Sağlık Çalışanlarının İş Güvenliği Algısının Belirlenmesi”, Türk Hava Kurumu Üniversitesi S.B.E. Yüksek Lisans Tezi, 2014, s.54.

[18] ÇİL, Güldane, "Hastanede Çalışan Hemşirelerin İş Güvenliği Düzeyinin Saptanması” K.K.T.C. Yakın Doğu Üniversitesi S.B.E. Yüksek Lisans Tezi, Lefkoşa, 2016, S.81. 